\title{
THE EUROPEAN COMMISSION AND THE MANAGEMENT OF EUROPE: PAST, PRESENT AND FUTURE
}

\section{David Ramiro Troitiño}

Tallinn University Of Technology, Tallinn, Estonia

\section{(C) MESTE NGO}

JEL category: N44, H, H2

\begin{abstract}
The paper covers the foundation, historical development, current situation and future of the European Commission. The management of the European affairs is in many cases in the hands of the Commission and how is composed in the future the organization will have a huge impact in the general management of the EU. The scientific analysis is based on a multidisciplinary approach with emphasis on the political role of the institution as it is starting to play a central role in the European Integration plus the management role of the Commission inside the EU. The future of the EU Commission is a key question for the future of the Union and is addressed by different proposals developed in this article.
\end{abstract}

Keywords: European Commission, subsidiarity, co-decision, future reforms, European Union, European Institutions, European Integration, management of the EU

\section{INTRODUCTION}

The European Commission is an important institution in the current European Union as it works as the executive branch of the organization. Its main aim is working for the benefit of the whole of Europe without, at least theoretically, any national influence. It makes this institution the center of the possible future European government, and hence, center of the European integration.

The first European Community, the European Coal and Steel Community, had institutions similar

Address of the author:

David Ramiro Troitiño

䤵p perdices57@yahoo.es to those of the EU but the institutions had different powers and tasks. The High Authority played the role of the Commission, but it had more power than the current institution. According to different theories of European integration, especially neofunctionalism, the integration process needs institutions to protect the integration already done, lead further integration in the right direction, and push for more integration. As Jean Monnet, one of the architects of the institutional framework of European integration, was the first president of the High Authority, he pushed for his way to have a strong institution without influence of the member states, far from the national interest and close to the European idea. The High Authority was by far the strongest institution in the ECSC. The Council, an institution that represented the member states, 
played a minor role. Hence, the common influence through the common institution was higher than the national influence played by the national governments of the member states of the organization. The beginning of the integration was promising for the European Commission.

Nevertheless, during the negotiations for the creation of the EEC and the EURATOM, France wanted to change the model, giving more power to the Council, the representation of the member states and taking away many functions from the previous High Authority or the new European Commission. So instead of being developed further, the model established by the High Authority in the ECSC, suffered a big regression in terms of integration - it made an important step back.

\section{THE FIRST STEPS OF THE EUROPEAN COMMISSION}

In the beginning of the process France was the leading state inside the European Communities and also a state against Jean Monnet becoming the president of the new Commission, because of his fervent support to European integration - an idea on contrary to president de Gaulle's conception of Europe and France. The French president had problems with Monnet already since the World War II, because of the role of France in the European affairs. He was basically a French nationalist, whereas Monnet was really a strong believer of the European integration. De Gaulle, once in office, moved the headquarters of NATO away from Paris in order to reassert Frances independence from USA in the Cold War, and developed a strong bilateral relation with West Germany outside of the European Communities for increasing political force of France. He played a major role in many important European issues, such as the enlargement to United Kingdom, Ireland and Denmark, that he personally vetoed twice in order to protect the national interest of France, above the common interest of the Union. He was also fundamental for the development of the Common Agricultural Policy, nowadays the main policy of the European Union in terms of budget. France obtains the biggest benefit from this policy in the whole Union as its farming sector gets the highest level of protection.
The ideas of de Gaulle in terms of European integration were clear in two important facts during his involvement in European politics: the Empty Chair crisis and the Fouchet proposal. The empty chair crisis was a consequence of the integration level in the European Communities, approving that the Council would work with qualified majority and dismissing the veto possibilities of any single state. It meant a big share of sovereignty as the majority of the member states could force some state to accept a proposal even if it was against it. De Gaulle stopped it as it could have enabled France to be outvoted in the Council.

The Fouchet proposal tried to change the whole essence of the European Communities from supranational to international organization, from a community based on integration to a new Community composed of a voluntary union of independent states. He also proposed moving the location of the European institutions from Belgium, Luxembourg, and Strasbourg to just one location: Paris, where the new secretariat would work instead of the European Commission - an institution that represented the European level.

The ambition to substitute the Commission with a secretariat was an obvious attack on European integration, substituting the independence of the Commission for national control, mainly French control. Its commitment to the European good made this institution illustrative of what de Gaulle disliked. He attacked the Commission constantly, complaining about not being representative of the European societies it was meant to serve, in other words a dictatorship created by civil servants without any democratic support.

On the other hand, Jean Monnet, the father of Europe had a long term involvement in the European integration. Already in the World War I Monnet developed a multinational navy for the allies based on the idea of sharing. In the WWII he created a plan of common citizenship between France and United Kingdom, as both countries were facing the same enemy, Germany, whom they had to fight together - for Monnet sharing the same duties meant sharing the same rights. As France surrendered very fast to the German troops, the plan did not work. Monnet was also the main contributor to the ECSC, and the main architect of the institutional building of this 
Community and president of the High Authority. The ECSC followed his believes that sharing the power will increase the integration between the member states decreasing the possibility of conflicts. Monnet also contributed to the creation of the EURATOM and was all his life involved in the European integration as a force behind most of the important decisions made.

The veto of de Gaulle meant Monnet's withdrawal of the candidature to the presidency of the European Commission and the nomination of Walter Hallstein as the new president. Hallstein was a scholar who had been the head of the German delegation negotiating the Schumann plan and the ECSC. He had a strong personal relation with the German Chancellor, Adenauer, making him a powerful man in terms of politics. He used his influence for developing the European Commission, providing it with respectability and a technocratic approach. His international representation of the Communities in trade negotiations, under the power of the new Commission, gave the European institutions international presence. But the problems about different European issues with France, and especially with de Gaulle, weakened its position. The French Premier used to attack Hallstein calling him an orient monarch sitting in his throne without any touch of reality, without any power, just acting as the premier of a non-existing country, the United States of Europe. Finally, Hallstein withdraw in 1967 (Ocaña, 2003). Nevertheless, his determination and enthusiasm were crucial in speeding up integration, especially in the Common Market, giving shape to the organization and providing it with the main direction, that the further development of the institutions should follow in the future. Hence, the work of Hallstein was crucial, and his influence can still be felt in nowadays European Commission. The current European Commission was shaped during the constant fights of de Gaulle and Monnet, between the French president and Hallstein. And most of the current problems are a direct consequence of this period, overall the lack of democracy and the technocratic essence of the Commission. The impossibility of developing a more political institution because of the opposition of de Gaulle meant the development of a more bureaucratic Commission based on a technocratic approach, as its main function was the development of the rules creating the Common European Market. The Council and the Commission, were just the executive body of the organization without being elected by any democratic election - there was no need to link the Commission with the European people, there was no need to link the Commission with democracy as it was mainly a body formed by civil servants, developing technical common rules in order to achieve a common market in Europe.

The further development of the European Union gave more and more power to the European institutions, specially to the European Parliament and the European Commission, as both bodies represent the European interest, but it all has created a big problem of legitimacy. The Commission is still an institution formed by civil servants with technocratic approach, but its political influence has increased enormously in the past years without increasing its democratic support. It has led to the main problem of the European Commission - its technocratic essence far from the people of Europe without any direct democratic support. The development of the power of the Commission has not been complemented with popular legitimacy, creating a big democratic deficit. (Ramiro Troitiño, 2013)

\section{CURRENT ORGANIZATION OF THE EUROPEAN COMMISSION}

The European Commission is organized with a presidency, a college of Commissars, and more than 40 Directorates-General (DGs), similar to the ministries of the states as they are organized by different policies. At the moment there are four main groups of DGs: Policy DGs, External relations DGs, General Service DGs, and Internal Service DG, entailing all the policies under the power of the European Commission. The Commission has 27 Commissioners, one from each member state, working together, including the president and 7 vice-presidents. Each Commissar has a specific area of influence, and it can entail one or more DGs. Traditionally some citizens of member countries held portfolios important for their national interest, as France did with Agriculture and Rural development (now in the hands of a Romanian, Dacian Cioloş), or Germany with the Internal Market (now under the 
power of a Frenchman, Michel Barnier). But in both areas, most of the civil servants working for the Commission belong to France in Agriculture, and to Germany in the Interior Market, and hence the influence of these two countries over these policies is still very important. The reasons are obvious: the importance of Agriculture for French farmers, as France is the main beneficiary of the $\mathrm{CAP}$, and the importance of Internal Market to Germany as the leading trading country of the Union. It raises the question of the independence of the Commissars and the staff of the Commission. Nowadays, nationals of the bigger countries of the Union acting as Commissars, hold important policies of the Union. And the smaller states hold other policies with less power, less budget, less staff, and less influence in the development of the Union. The current Commission is a good example with a French citizen in charge of the Interior Market - one of the most important fields in European integration; a German responsible of Energy, a priority for the German government nowadays because of its influence in economic productivity; a Brit of foreign Policy and an Italian of Industry, whereas the Commissars from Malta or Cyprus or Bulgaria are in charge of minor policies. It means that the influence of the member states is very important in the composition of the European Commission, and national interest is still an important fact in the designation of the Commissars.

\section{ELECTION OF THE MEMBERS OF THE COMMISSION}

The Commission is elected in such a way that the influence of the member states is fundamental. The presidents or prime ministers of the member states negotiate among themselves as to who is going to be the president of the Commission. The way that they choose the president is a mystery, without any voting system, without any clear procedure, without any public control, just secret negotiations between the most influential members of the Union. According to the Treaty of Lisbon, the president should be chosen by a qualified majority of the Council, but normally the secret negotiations of the member states have already decided on a candidate for the post, before any candidate is presented. This procedure has been highly criticized by the European
Parliament for not being democratic, and not respecting the Treaties, but little has been done to improve this situation. (Parliament, 2012)

Also, the Council should take into consideration the result of the latest European elections, and normally the president should be chosen from the same political family that won the latest elections, in order to implicate the election of the president of the Commission more with the European reality. It could indeed give the Commission a more democratic background.

The presidents of the Commission, who are nationals from France and Germany, have been more influential in European integration, as the German Hallstein or the French Delors, because they have more influence and links to their national governments - the leaders in the European building process. On the other hand, we have presidents from smaller countries: like Barroso from Portugal, who has no strong links with the national governments of the main states of the Union, and hence, his influence and capacity are smaller.

After the president is chosen by the Council, he has to obtain the approval of the European Parliament, and then, collaborating with the council, make up his team of Commissars. Then the whole Commission goes to the European Parliament, which can approve or reject the whole Commission. On different occasions the member states did not nominate very appropriate people to the Commission in terms of professional capacities or nominated people who were under national controversy, so in some sense the Commission became a graveyard of national politicians. This tendency disappeared after the reform that gave the power of appointing the Commission to the Parliament and recent years we have seen how the threat of the Parliament has led to withdrawal of inappropriate candidates, such as the Italian candidate Rocco Buttiglione, who as commissar of Justice, Freedom, and Security, did not hide his negative opinions about homosexuals and women (Holmes, 2004). Finally the Italian government presented another candidate for the post because otherwise the whole Commission would have been rejected by the Parliament. 
In short: the way that the president and the commissars are chosen has created a big debate about the democratic grounds of the institution. As the Commission has a big impact in the lives of European citizens, the European people should have some say in the procedure. There are different proposals: European elections for the president of the Commission among them, but it would be difficult, because there are really no European political parties, just political families, and the participation in the European elections is very low compared to national elections. On the other hand, if the elections would be more interesting, with different candidates and different programs for the Commission, Europeans could feel closer to the Union and maybe, participate more. Another possibility is that the president of the Commission could be chosen just among the members of the European Parliament. As the members of it have been chosen by the Europeans, it would have more democratic background than the current system. But that is also unlikely to happen in the short term, because the member states would lose the control they have on the nomination of the president of the Commission now. It would also give more power to the Parliament - another institution that is having problems with democracy and representation of European citizens. The reform is probably far off, but as integration increases and the power of the institutions also grows, getting closer to some sort of European government, the people will want to participate in the election of the president of the Commission; and the second option - to choose a member of the Parliament, will probably work in the medium term.

\section{WORKING SYSTEM}

The Commission works as a whole, as a group, where all decisions are taken by the whole team of commissars, and hence they as a whole are responsible for the decisions taken. This collegiate system does not mean that there is no debate inside the Commission, or that the commissars always agree on everything, but the debates and dissensions are close to the commissars and the president of the Commission. When they reach an agreement, all the members have to support it. This working system means that the Commission is united for good and for bad, and the whole
Commission is responsible for the actions of all its members. Hence, as we have been shown in the procedure to elect the Commission, the European Parliament can only accept or reject the whole team, not parts of it. Also, the Parliament has some control power over the Commission and can dismiss the whole Commission, but never just a commissar, as it happened in the case of mismanagement of funds by the commissar Cresson and the fall of the whole Commission under Santers presidency because of the pressure of the European Parliament. (Health, 2009) As Mario Monti, commissar of the Santer's Commission said "This Commission has collectively resigned, I believe, not because of collective responsibility but because certain members of it preferred not to take their own individual responsibilities." Nowadays the Commission is still working with the same system, but the enlargements have meant more and more commissars, reaching 27 members of the Commission, so it has become difficult to maintain the collegiate system, and currently Barroso has a more presidential style.

The European Commission has its own staffaround 33,000 people working in the different services of the institution. The size of the Commission has often been criticized for the great numbers working there, but if we compare it to the civil servants working in the member states, and the citizens they have to deal with, the European Commission is a really small institution. The 33,000 headed staff of the Commission work for a European population of almost 500 million people (The EU-27 population continues to grow, 2009). France, for example, has more than 2 million civil servants (This number is an estimation of the French civil servants in all the levels of the state, as central, regional, and local institutions. So, it cannot really be compared with the European Commission, as it is just one institution of the Union, even when it is the largest) for a population of 64 million people, (Service-public.fr, the official gateway to the French civil service, 2010) so the size of the Commission is not as high as the critics point out. The criticism originates mainly from the times of the British Premier Thatcher and her beliefs in reduction of the size of the state and trust in the market as a regulator of economic agents, hence in the citizens. Thatcher did indeed reduce 


\section{Troitino D.R. The European commission and the management of Europe}

\section{MEST Journal Vol. 2 No. 2 pp. 241-250}

the numbers of civil servants in the local and regional institutions of the UK, but in the central government she increased them, and in her battle with European integration, she also wanted to decrease the influence and the numbers of the European Commission. Traditionally these critics have come from British soil.

The services of the Commission with highest numbers of civil servants are the DGs of Development Aid (12\%), the Join Research Center (8.3\%), and the translation service $(7.3 \%)$; and the services with the fewest people working there are the BEPA or policy advisers $(0.1 \%)$, the JAS $(0.3 \%)$, and CLIMA (0.4\%). About the internal composition of the Commission, it is remarkable that there are more women $(54.5 \%)$ than men $(45.5 \%)$ working there, so there are no major gender equality problems. The countries with the most nationals working in the European Commission are Belgium (18.3\%), Italy (11.1\%), and France (10.2\%); the geographical localization of the Commission with its main center in Brussels explains the high number of Belgian citizens working in the Commission and the high number of French and Italians is explained by the size of both countries. Anyway, here the surprise is the comparatively low number of Germans working for the Commission (6.9\%) because Germany is by far the most populous country of the Union. Also the UK presents a low rate compared with its population (4\%). The countries with the lowest presence in the Commission are Cyprus (0.4\%), Malta $(0.5 \%)$, and Estonia $(0.6 \%)$ - in a normal accordance to the size and the population of these states. (Staff figures, 2013)
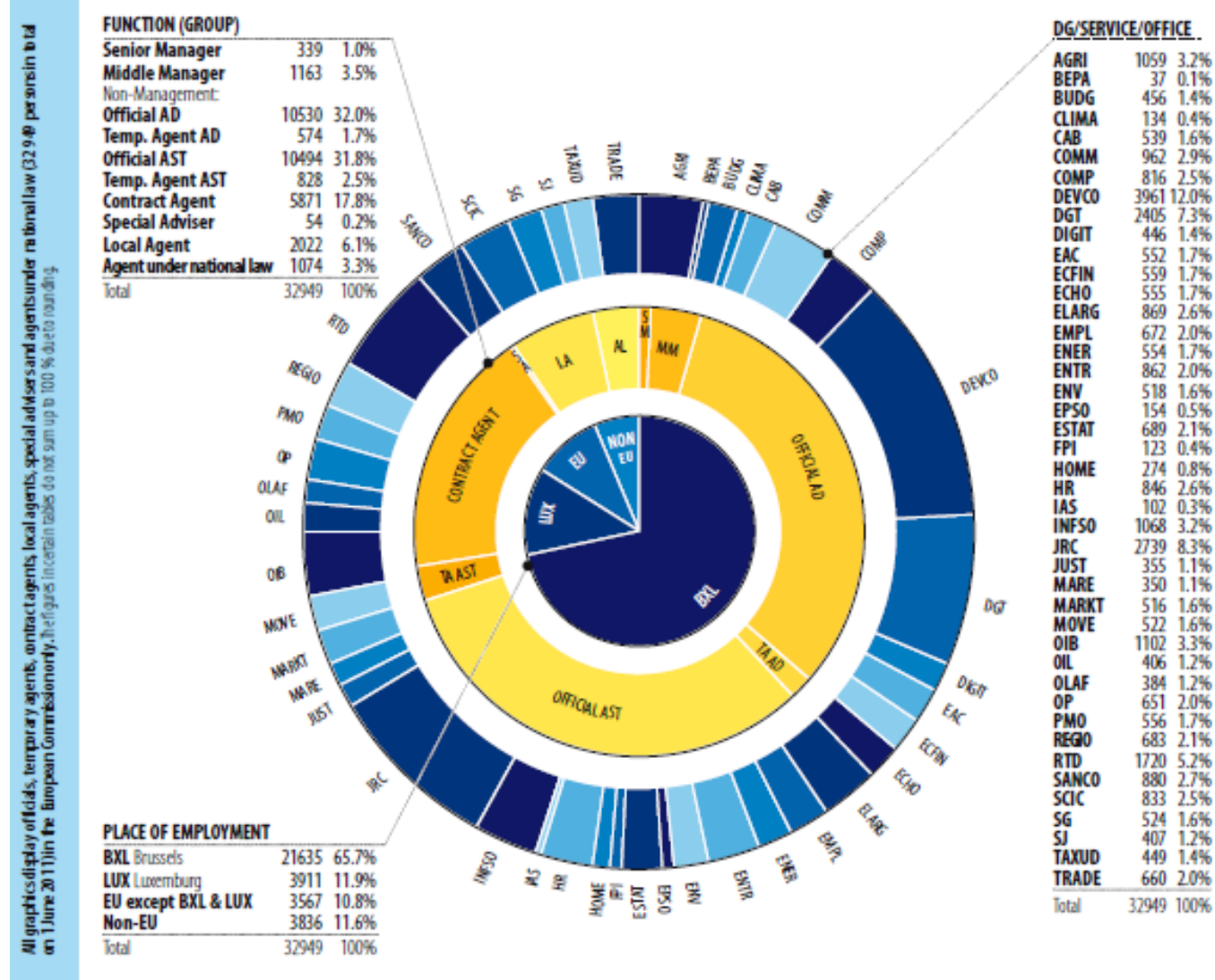

Fig. 1 The European Commission staff numbers

Source: European Commission (Staff figures, 2013)

\section{LOCATION OF THE COMMISSION}

Originally the High Authority was located in Luxembourg, but the concerns about new European institutions and the impact of the civil servants of the Commission in the reduced population of the country led to choosing a new location for the European Commission. Belgium, because of its central location and because of the multinational composition of the country, was 
selected to be the new headquarters of the new institutions. The primary development of the Commission centralized most of its services to Brussels, with the exception of the ECSC, which is still located in Luxembourg. The location in Brussels has created some problems, because the EU was accused of imitating the most centralized states. The offices of the president of the Commission are located and the weekly meetings of the whole Commission held also in Brussels. This critique of centralizing plus the development of the new technologies that improve the communications so much are leading to the establishment of services of the Commission in other locations, such as Spain, Denmark or Finland. Also, the external services of the Commission and its representation in other states accounts for a big share in the European Commission. So, the workers of the Commission are located in Brussels (65.7\%), Luxembourg $(11.9 \%)$, other member states $(10.8 \%)$ and territories outside the Union (11.6\%).

\section{THE POWERS OF THE EUROPEAN COMMISSION}

The powers of the Commission are mainly executive power, legislative initiative, and enforcement of legislation. Executive power is shared between the Commission and the Council. Until the Treaty of Lisbon executive power was in the hands of the Council, and this institution delegated it to the Commission. It was a clear movement from the member states controlling the Commission, because in case of any big clash between both institutions - one representing the interest of the member states and the other representing the interest of Europe - the Council could withdraw this power from the Commission. It never happened, but it was an option for enforcing the position of the Council. After the Treaty of Lisbon the Commission holds executive power by itself as it is in the treaties, but not all executive power: the Council still holds the executive power in such important areas as Foreign Policy or the executive power of the common currency in the hands of the European Central Bank. The executive power of the Commission is more restricted than most national executives, but it is very important on the
European level, equating the Commission with some kind of government of Europe.

The legislative initiative is one of the most important powers of the Commission. It means that this institution is the only one that can initiate legislation in the Union. The procedure starts with the consultation of the Commission with different groups of independent experts, and the debate and reform of this legislation in the different services of the Commission related to the field, until final approval by the college of commissars. Then the proposal is no longer under the influence of the Commission and goes to the Council and the Parliament to be approved, including amendments to the original proposal of the Commission. However, at the early stages of the process the Commission can withdraw its proposition for new legislation if the Council and the Parliament completely change the spirit of the proposal.

The main reason to give this power to the Commission is based on the neo-functionalist theory of European integration, where an independent institution is needed in order to push the integration in the right direction without the influence of the member states. The power of legislative initiative of the Commission will lead integration according to the European interest, and hence without the influence of national groups. Nevertheless, the Council and the Parliament can ask the Commission to start the legislative process on anything they consider necessary, and the Commission can refuse, but normally always accepts. European citizens (at least one million) also can ask the Commission to draft new legislation, but the petition is not binding. There are some fields where the Commission does not have the power of initiating legislation as with the Common and Security Policy, where the member states reserve this power for themselves.

Finally, there have been critics of this monopoly of the Commission because of the poor democratic record of the institution, as it is elected by the Council and the Parliament without any link with European citizens. The Parliament would also like to have this power, or at least share it with the Commission. Besides that, the Commission also initiates the procedure of creating the new budget 
of the European Union each year. As with the rest of the legislation, the draft of the budget created by the Commission is transformed by different amendments introduced by the Council and the Parliament.

Among the more notable powers of the Commission is controlling the good implementation of European legislation in the member states of the Union, also the Commission is in charge of implementing the European budget. Normally the Commission uses the institutions of the member states to control that the implementation is correct, but it also uses some of its own agencies. It is important to remark that the Commission does not have the right of punishing - according to the Commission itself this is bad implementation of European legislation. Usually the Commission tries to point out a deficiency to a member state, and after that the anomaly is solved. If the state does not share the opinion of the Commission and does not apply any change to the observations, the European Commission cannot sanction the state, but can send the case to the High Court of Justice, the institution that will decide and sanction, if such action is relevant. The European Commission acts as the Guardian of the Treaties (Garcia, 2000).

The Commission also has other and different powers besides these three main ones, highlighting the international representation of the Union in world trade organizations, as trade policy depends on the Commission, because it has influence on the European level, surpassing the national sphere.

\section{MAIN PRESIDENTS OF THE EUROPEAN COMMISSION}

The most important presidents of the European Commission have been Hallstein, Delors, and Santer. As the president of the Commission sets the agenda of the institution and his personal influence is broad, the personality and the attitude of the president are very important for the achievements of the organization. Hallstein developed the organization, while Delors gave a big impulse to European Integration, adding dynamism and giving the Community a sense of direction, pushing for more integration in the Single Market and the creation of the monetary
Union. Santer is the most negative figure because his Commission had to step down due to financial mismanagement. The current president of the Commission, Barroso, is a minor character in European integration as his actions are mild and the institution has lost presence in leading the European building process.

\section{CONCLUSIONS}

The European Commission has been criticized as the European citizens see the Commission as something alien, something located far away in Brussels without being in touch with the reality of citizens, having huge salaries. The Commission is trying to solve this problem with more transparency in the working system of the Commission and with active press action to bring the institution closer to European citizens, but it will not work unless there is a direct link between the European citizens and the European Commission. To create that link there are different possibilities - the most obvious of them a direct election of the Commission in European democratic elections.

Also, Commissions role to push for deeper integration is seen as an attack on the national states and the liberties of citizens, for example Commissions support to enlargement to Turkey, when many European citizens are against it, or at least wanting to have a say on the issue. The Commission is always going to push for deeper integration, because it is one of its most important roles in the architectural framework of the European building process. It is its duty, and sometimes this approach does not match with the wishes of the European people or the member states, more prudent in terms of integration. In reality there are other institutions in the European Union to avoid a dictatorship of the Commission, the rule of technocrats. These institutions deal with the problem of who has stronger links with the European people: the European Parliament via the European elections, or the Council, via national elections where the national governments are chosen (Brown, 2011). So it is basic to keep a balance of power between the different European institutions in order to preserve the integration process in track. 
In the current economic crisis the European Commission is trying to increase its role in the European affairs, increasing highly the euro skepticism among Europeans. The members of the Commission criticize some policies of the member states and propose reforms to the national governments, but they do not have any democratic power and hence their position is not understood by the people of Europe. The Greek, Spanish, Italian, Irish or Portuguese population cannot understand how the country has to follow the proposals of the Commission when this institution is mainly a technocratic body of civil servants who earn thousands of euro a month and are living in a European bubble without any contact with the reality and necessities of the people. Again the lack of democratic background of the Commission is its biggest enemy.

The future of the Commission will be linked with the speed of integration in Europe. As currently it seems that the priorities are focused on the common currency and the possibility of creating an economic government in the Union, it seems unlikely that the Commission will be in charge. The most feasible solution would be the creation of an economic government under the umbrella of the Council, and hence total control of the members of the Euro zone. Then the duality of two executive bodies, the Commission and the Council, would be reaffirmed and developed. This, plus the attitude of the Council, which seems unwilling to yield the power of the Common Foreign and Security Policy to the Commission, would confirm this duality in the Union. The Commission, nevertheless, will try to influence the process and share some of the power of the Council as the democratic background of the Commission grows and its relation with European citizens increases. The next wave of integration is likely to deepen the role of the Commission as more policies will be included in the sphere of influence of this institution.
The future of the European Commission is also linked with the other most powerful European institution, the European Parliament, as the latter is the representation of the political will of the European people through the European elections. As the political role of the EP will increase, its democratic link with the European people will become stronger trough the creation of European political parties and the most likely political link with the European Commission. In order to give a saying to the European people in the Commission election and to increase the interest of the European people in the European elections to the European Parliament, it is most likely that the future European Commission leaders, the President and the Commissars will be elected between the democratically elected members of the European Parliament. It would be a very important step in the creation of the European State and the European government, so the political enemies of this option are numerous and powerful, but so will be the challenges of the European Union which will probably be solved following the spillover effect of the Neofunctionalism. Further integration creates benefits, but new problems as well. These can be overcome just with deeper integration. According to this model, there will be a moment where deeper integration will be a necessity and the actors involved in the process will have to decide between the collapse of the organization or deeper integration, more power with democratic support to the European Commission or the end of the European Union.

The path is long and full of formidable obstacles, but the options are reduced as the integration increases and the individual measures of the member states have not effectiveness to solve the problems of their citizens. So Europe becomes the most likely option to manage the problems of the European societies in common.

\section{WORKS CITED}

Anon. (2010, 01 18). Service-public.fr, the official gateway to the French civil service. Retrieved 0318 , 2014, from Service-public.fr: http://www.service-public.fr/langue/english/

Anon. (2013, 12 31). Staff figures. Retrieved 03 18, 2014, from European Commisison: http://ec.europa.eu/civil_service/about/figures/index_en.htm

Brown, M. (2011, 10 26). European Union: The European Commission Reacts to Criticism: New Best Practices on the Conduct of Antitrust Procedures Published - Emphasis on Transparency and 
Troitino D.R. The European commission and the management of Europe

MEST Journal Vol. 2 No. 2 pp. 241-250

Procedural Rights. Retrieved 03 18, 2014, from mondaq: http://www.mondaq.com/x/150636/Antitrust+Competition/The+European+Commission+reacts + to + Criticism+New+Best+Practices+on+the+Conduct+of+Antitrust+Procedures+published+E mphasis+on+Transparency+and+Procedural+Rights

Garcia, I. S. (2000, 03 24). WRITTEN QUESTION E-0908/00. Retrieved 03 18, 2014, from EURLex.europa.eu: http://eurlex.europa.eu/LexUriServ/LexUriServ.do?uri=OJ:C:2001:046E:0077:0078:EN:PDF

Health, R. (2009). Recent Scandals. Retrieved from EU Facts: http://www.eufacts.org/en/scandals/index.html

Holmes, S. (2004, 10 21). Profile: Rocco Buttiglione. Retrieved from BBC News: http://news.bbc.co.uk/2/hi/europe/3718210.stm

Ocaña, J. C. (2003). Walter Hallstein. Retrieved from Pioneers of European Unity: http://www.historiasiglo20.org/pioneers/hallstein.htm

Parliament, E. (2012). European Parliament / MEPs. Retrieved from European Parliament: http://www.europarl.europa.eu/members/archive/alphaOrder/view.do?id=1308\&language=EN

Ramiro Troitiño, D. (2013). European Integration, building Europe. USA: Nova science Publishers.

Retrieved from Eurostat: http://epp.eurostat.ec.europa.eu/cache/ITY_OFFPUB/KS-QA-09-031/EN/KSQA-09-031-EN.PDF

Received for publication: $\quad 19.01 .2014$

Revision received: $\quad$ 18.03.2014

Accepted for publication: $\quad 03.06 .2014$

How to cite this article?

Style - APA Sixth Edition

Troitino, D. R. (2014, 07 15). The European Commission and the management of Europe: past, present and future. (Z. Čekerevac, Ed.) MEST Journal, 2(2), 241-250. doi:10.12709/mest.02.02.02.24

Style - Chicago Fifteenth Edition:

Troitino, David Ramiro. 2014. "The European Commission and the management of Europe: past, present and future." Edited by Zoran Čekerevac. MEST Journal (MESTE) 2 (2): 241-250. doi:10.12709/mest.02.02.02.24.

Style - GOST Name Sort:

Troitino David Ramiro The European Commission and the management of Europe: past, present and future [Journal] // MEST Journal / ed. Čekerevac Zoran. - Belgrade : MESTE, 07 15, 2014. - 2 : Vol. 2. pp. 241-250.

Style - Harvard Anglia:

Troitino, D. R., 2014. The European Commission and the management of Europe: past, present and future. MEST Journal, 15 07, 2(2), pp. 241-250.

Style - ISO 690 Numerical Reference:

The European Commission and the management of Europe: past, present and future. Troitino, David

Ramiro. [ed.] Zoran Čekerevac. 2, Belgrade : MESTE, 07 15, 2014, MEST Journal, Vol. 2, pp. 241-250. 